DOI 10.14746/ssp.2019.3.2

\title{
Marta BALCEREK-KoSIARZ
}

Adam Mickiewicz University in Poznań

ORCID: 0000-0002-7899-6683

\section{Multi-level governance in local governments in the Federal Republic of Germany ${ }^{1}$}

\begin{abstract}
Performing public tasks as part of multi-level governance, municipal governments in Germany play the most vital role in the network system. As state bodies, they initiate and change the forms of coordination of collective actions. The main issue addressed in this paper is the use of a conceptual grid applied in the deconcentrated structure of public administration in Anglo-Saxon countries for the description of multilevel governance in decentralized forms of public administration. The main aim of this paper is to present how the concept of multi-level governance has been adapted to the specific character of German municipal government and what its essence is. The following research questions are asked to achieve the main aim: What is the difference in the genesis of governance in Germany in comparison to the tradition of Anglo-Saxon countries? How are public tasks performed within the framework of multi-level governance in Germany? What are the organizational and legal forms of performing public tasks? The paper was prepared following the assumptions of the new institutionalism. In order to present ways of performing public tasks in the concept of multi-level governance the functional method was used. This enabled the selection of those tasks that can be implemented by both local government units and self-governing business institutions. Additionally, the institutional method was used to show the specificity of cooperation between municipal governments and other public and private entities. The research on multi-level governance in Germany resulted in three conclusions providing the framework for this paper. Firstly, the emergence of multi-level governance in Germany has been based on top-down activities which occur between the federal states and municipalities. The creation of network systems results from the conviction of the state authorities that the implementation of public tasks is more effective in cooperation with private organizations which are moderated by regulatory entities. Secondly, before implementing multi-level governance on the local level, regional governance has been established at the level of the Lands, allowing the concept of governance to be adjusted to the specific requirements of a federal state. Thirdly, multi-level governance has been embedded in the structure of local government through a specific type of public task (Gemeinschaftsaufgaben).
\end{abstract}

Key words: municipal government, local government, public tasks of municipal government, governance, multi-level governance, public governance

1 The project was financed from the funds of the National Science Center granted on the basis of Decision No. 2012/07/N/HS5/01705. 


\section{The genesis of multi-level governance in the Federal Republic of Germany}

The main issue addressed in this paper is the use of a conceptual grid 1 applied in the deconcentrated structure of public administration in Anglo-Saxon countries for the description of multi-level governance in decentralized forms of public administration. The main aim is to present how the concept of multi-level governance has been adapted to the specific character of German municipal government and what its essence is.

The German literature on this subject roots the strategy of multi-level governance in the concept of governance. In the United Kingdom, Ireland and the United States this can be seen in the competences to coordinate public policies being transferred by way of deconcentration (Ansell, 2000, p. 279). In the Anglo-Saxon tradition, governance - understood as ruling or management - is the object of in-depth studies of the following issues:

- coordination of public policies implemented by public administration bodies at the central and local levels;

- analysis of tools at the disposal of public and private entities pursuing regional and local development;

- setting the limits to and manners of intervention of public authorities on the market;

- ways of exercising power (Kaufmann, Kraay, Mastruzzi, 2009, p. 5);

- methods of cooperation and negotiation rather than coercion (Ansell, 2000, p. 281);

- relationships between the groups of entities within a network (Jessop, 2007, p. 6).

The German literature on this topic emphasizes that governance emerged in Germany in the 1970s as an outcome of transformations taking place in three areas. Firstly, the new public governance and public-private partnerships were adjusted to specific German conditions and spread on a large scale. Secondly, local associations, interest groups and private actors were increasingly involved in creating local policies based on a policy partnership of interested entities in civil society in Germany. Thirdly, new forms of civil involvement were launched in Germany (Denters, Rose, 2005 , p. 46). Fourthly, Germany continued its broad alliance and the cooperation of local government at the municipal level with self-governing business entities, in particular chambers of commerce and industry.

In order to distinguish the Anglo-Saxon concept of governance, the term 'regional governance' was introduced in the German literature on 
this topic, meaning "loosely institutionalized forms of performing tasks within the network cooperation of regional actors created to achieve regional development" (Benz, Fürst, 2003, p. 12). Another explanation worth quoting is that by Dietrich Fürst, who stressed that "regional governance is based on the network cooperation of entities operating in the sectors of politics, business and society. Their activities are based on the joint designing of a local development strategy" (Fürst, 2001, p. 370). To provide an exhaustive definition of local governance, the following properties need to be taken into consideration: voluntary membership of both public and private entities, lack of established operating principles, low level of institutionalization, operating independently of the hierarchical central government administration and the cooperation of institutions representing various interests, which can be fulfilled only through cooperation (Fürst, 2004, p. 45).

The adaptation process of the governance strategy in Germany was supposed to take into account its specific federal system. The Anglo-Saxon and German approaches to the concept of governance are similar, in that it is an indirect form of public governance. In the Anglo-Saxon tradition it operates within the hierarchy of central administration, whereas in Germany it is implemented within a framework of decentralized organizational structures which have been granted regulatory administrative power, allowing them to establish laws and enforce them on people operating in the area concerned (Böcher, 2008, p. 33). Thus they provide a 'third way,' enabling the extensive participation of entities surrounding local government units, forming alliances to execute and manage public tasks more effectively.

Having discussed the scope of the concept of governance, it can be concluded that it is difficult to examine this concept in the case of the local government units which constitute decentralized forms of public administration according to the Anglo-Saxon criteria. A separate approach to governance should be taken for countries with decentralized public administrations in which governance is characterized by the following properties:

- coordination of public policies which correspond to the tasks stipulated in respective legislative acts performed in conformity with the specific nature of a given territory;

- analysis of organizational and legal forms of operation of public and private entities performing their own, and commissioned tasks;

- monitoring the effectiveness of tasks performed in terms of goals fulfilled; 
- activities of municipal government pursuing entrepreneurial development in its area;

- investigating the scope of intervention on local markets in terms of exercising regulatory and non-regulatory administration;

- comparison of different forms of cooperation of local government units on the examples of specific purpose associations (Zweckverbände), municipal working groups (kommunale Arbeitsgemeinschaft) and public-private agreements (öffentliche Vereinbarungen);

- local government units forming relationships between network groups by virtue of unilateral regulatory acts.

On the basis of the above-presented characteristics of governance in a decentralized public administration, it transpires that the role of public authorities has changed and it should no longer be about policy creation, but rather about focusing on moderating various aspects of local public policies which correspond to specific tasks stipulated in legal acts. In terms of governance, public administration, including its essential element - local government - is part of the organization of social life, and participates in solving collective problems together with individuals and groups concerned, or their representatives.

It can be concluded that the concept of governance has been adapted to the specific character of Germany. This adaptation required proper criteria to be developed. Governance in Germany is based on the premise that municipal governments are a decentralized form of state administration and play an essential role in developing different forms of cooperation with other public and private entities. The term 'governance' can therefore be highly comprehensive. Examining the range of mutual relationships between public and private entities, indirect forms should be given priority, as they combine the needs and interests of those entities generating socio-economic progress in a given area.

One form of governance is multi-level governance. It dates back to the 1970s as a form of co-governance and is an outcome of regionalization and Europeanization processes (Scharpf, 2014, p. 80). Originally, the term was used with reference to the supranational and national levels only. However, when regional development policies were transferred from the central level to that of Lands it became necessary to develop new coordination mechanisms for entities operating in their respective areas to use their potential to promote socio-economic progress (Giessen, Böcher, 2009, p. 211). It was then that the political system of Germany began to be analyzed in terms of cooperation between different entities 
merging to develop new values, so as to increase the competitiveness of their territories.

Multi-level governance in Germany is related to two concepts which are an outcome of the legitimization crisis of state institutions and representative democracy, namely the low effectiveness of public services and representation of interests (Strumińska-Kutra, 2012, p. 17). It turns out that solutions solely based on a regulatory administration providing public goods and services are ineffective. It was also no longer viable to order such goods and services from private entities under the New $\mathrm{Pu}-$ blic Management, whereby local governments focused on the generation of profit. Under the New Public Management, local governments carried out business operations to protect their property, using different solutions provided by civil law (Lepsius, 2002, p. 313). This model is based on a non-regulatory (servicing) administration whose bodies are active local actors managing property, who adjust market solutions to public administration. This also involves the matter of gathering more property than is necessary to carry out the tasks. On the other hand, such property should be accumulated to ensure continuous and uninterrupted fulfillment of all the needs of local community members in the event of a crisis.

This attitude was inspired by the financial crisis of municipalities in the 1980s. The following reasons for the crisis have been identified: insufficient resources provided for the implementation of tasks by municipalities; too high debt repayments; falling returns on investment, increasing costs of administrative staff, too many tasks transferred; the lack of a workable policy to generate returns on investment, taxation decisions made by the state and individual Lands; limitation of public debt in connection with Maastricht criteria (entry criteria to economic and monetary union) and the costs of German reunification (von Mutius, Henneke, 1985, p. 3).

The New Public Management in Germany has not transformed into New Local Governance, the way it has in Anglo-Saxon countries, but into a New Steering Model (NSM - Neues Steurungsmodell). The model was a result of the bottom-up initiative of municipalities which endeavored to alter the manner of their operations without support from the central administration (Sześciło, 2012, p. 50). The NSM was developed by the association for administrative governance (Die komunnale Gemeinschaftstelle für Verwaltungsmanagement). This model included five characteristics:

- to strictly separate policies from administration - public policy creation should be performed separately from current federal policy; 
- management contracts should be introduced between higher managers and organizational units in their charge;

- the management of administrative resources should be decentralized;

- special units to steer and monitor administrative activities should be established.

This new direction of transformations in the field of public governance laid the foundations for participatory models of exercising public tasks to be introduced which can be implemented within multi-level governance.

The source of multi-level governance is therefore the change in the management style of public administration and the departure from the model of a bureaucratic government in favor of a governance model based on different means of coordination using markets and networks (Bevir, 2011, p. 1). In practice, this takes the form of decentralization processes and the cooperation of entities from the public, private and social sectors in the field of governance (Hausner, 2007, p. 493). The entities included in the multi-level governance strategy in Germany included local government units, as well as self-governing business institutions, such as chambers of commerce and industry, chambers of agriculture and chambers of crafts, as forms of decentralized public administration.

\section{The implementation of public tasks within the framework of multi-level governance}

The implementation of public tasks within the framework of the multilevel governance strategy in Germany is related to the problem with the coordination of such tasks. The problem here is about using the specific Anglo-Saxon concept of governance which emerged in deconcentrated public administration (central administration) exercised by decentralized forms of state administration (local government administration). Governance assumes that public (municipal government) and private entities operate on the same (local and regional) level. This results in problems regarding how the relationships between these institutions are formed. Taking into account the role played by municipal governments, it is worth considering in which situations market self-regulation works in the field of performing public tasks; in which fiats are applicable; and when co-governance is recommended. This is directly associated with the performance of tasks of regulatory and non-regulatory administration. These two types of administration represent the functions performed by local administration bodies. The administration 
of property consists of management by means of activities stipulated in administrative law. Managing, in turn, is based on forms stipulated in civil law that assume the equality of parties of a legal relationship, where it is inadmissible for one legal entity to authoritatively and unilaterally determine the situation of the other legal entity. The difference between regulatory and non-regulatory administration should be explained here. The former operates on the basis of unilateral legal acts regulating relationships between public and private entities. The latter provides public utility services for the performance of which public-private entities can be established.

Two types of multi-level governance can be distinguished. In one, a limited number of entities operate, performing similar tasks. Therefore, there are formally interdependent decision centers whose number is limited. It is thus imperative to have a limited number of the levels of power. The entities flexibly solve the problems they have been appointed to handle. The other type assumes the presence of multiple power centers performing separate functions. One can talk about an indefinite number of formally independent decision centers. There is also no limit to the number of the levels of power. As in the first case, the entities are highly open and flexible in solving problems emerging in a given area, or matters which exert considerable influence on this area (Hooghe, 2001, p. 7).

With reference to the above-mentioned types of multi-level governance, different ways of implementing public tasks can be identified depending on the public entity which plays the essential role in their performance. Such activity can be initiated by chambers of commerce and industry, chambers of agriculture and chambers of crafts. However, the implementation of the multi-level governance strategy can also be found in the structure of public tasks implemented by municipal governments, which especially concerns special public tasks (Gemeinschaftsaufgaben).

Taking as an example chambers of agriculture, they perform environmental protection tasks employing multi-level governance. As stated above, the first type of multi-level governance involves a horizontal alliance of entities in a single industry, e.g. environmental protection (e.g. chamber of agriculture, municipal government units, state forests, associations and foundations whose statutes provide for environmental protection, and residents of areas close to green areas). The focal point of the horizontal integration in the form of networks and coalitions is the overarching interest, such as environmental protection, rather than the individual interests of all entities. The network is formally founded on a shared program, integrated development strategies and plans, enabling cooperation and the implementation of 
regional and local projects. Tangible activities include the joint designing of environmental protection programs, air protection programs and development strategies. To achieve the synergy of public administration bodies, businesses and civil society entities, the programs and strategies have to be multi-dimensional and their impact should go beyond the objectives stated.

The other type of multi-level governance is embedded in the structure of the public tasks performed by municipal governments in the form of Gemeinschaftsaufgaben. The specific nature of these tasks lies in the general conditions for the cooperation of public and private entities established at the federal level to enable their implementation. These conditions are further detailed at the regional level where they are adapted to the specific demands of each Land. In the final stage, the tasks are commissioned to municipalities. These tasks typically go beyond the local dimension and concern, for example, postal services, transportation, spatial planning, economic supervision, finances, fees and taxes. A significant feature of the Gemeinschaftsaufgaben is that they are also implemented by other public administration bodies. Their other feature is their inherent subsidiarity. The principle of subsidiarity means that the tasks can be performed by local government units and - when these units are unable to do so - by central administration bodies. Besides providing the framework for the cooperation of public and private bodies, central authorities also design specific programs by means of which they provide financial aid to bottom-up initiatives which involve several different entities (Dolnicki, 2006, p. 101).

As a result of the activities undertaken, a new management model of public affairs emerges. Their direct consequences involve the change to the regional development strategy, which is based on the bottom-up activities of different institutions, leading to improved performance effectiveness of specific tasks in a given area (Giessen, 2010, p. 4).

In the above types of multi-level governance, local and regional entities are integrated, combining their respective assets of information, knowledge, human capital and financial measures. This makes it possible to accomplish more effective solutions to the issues of a given area. An indirect advantage involves increased approval for public authorities and the policies implemented by them (Giessen, 2010, p. 4).

The above analysis of the role of municipal governments in multi-level governance implies the following regularities in the performance of public tasks: - the vertical and horizontal disaggregation of the role of the state results in the multi-level structure of authorities, shared accountability and overlapping competences of different entities; 
- the operation of a limited number of independent and flexible decision centers (established as needs arise) is feasible;

- the state acts as an intermediary in the creation of vertical and horizontal network connections, in strengthening the importance of nongovernmental entities and as a coordinator of such connections;

- intermediate organizational forms between the market and organizations emerge;

- the significance of relationships (interactions) between the entities participating in processes of governance increases, which to a large extent depends on mutual trust;

- forms of coordination evolve from fiats to negotiations;

- the role of institutions increases;

- the significance of the bottom-up approach to the implementation of public tasks grows, alongside the importance of municipalities as places where knowledge and information are exchanged (Kopyciński, 2014, p. 36).

\section{Organizational and legal forms of performing public tasks within the framework of multi-level governance}

When examining the relationships between state administration bodies and private entities in the context of public tasks, attention should be given to the coordination mechanism of collective activities. This concept was introduced to Polish academia by Jerzy Hausner, who followed Walter W. Powell, and identified the following three mechanisms: organizations (hierarchy), markets (businesses) and networks (intermediate forms or hybrids). They are described in the table below.

Table 1

Typology of ways to coordinate activities

\begin{tabular}{||l|l|l|l||}
\hline \multicolumn{1}{|c|}{ Feature } & \multicolumn{1}{c|}{ Organizations } & \multicolumn{1}{c||}{ Markets } & \multicolumn{1}{c||}{ Networks } \\
\hline \multicolumn{1}{|c||}{2} & \multicolumn{1}{c||}{3} & \multicolumn{1}{c||}{4} \\
\hline Normative Basis & Imposed Principles & Contracts & Convention \\
\hline $\begin{array}{l}\text { Type of Relation- } \\
\text { ships between } \\
\text { Participants }\end{array}$ & $\begin{array}{l}\text { Domination - Sub- } \\
\text { ordination }\end{array}$ & $\begin{array}{l}\text { Competition and } \\
\text { Cooperation }\end{array}$ & Partnership \\
\hline Basic Instruments & Administrative & Economic & $\begin{array}{l}\text { Communication- } \\
\text { related }\end{array}$ \\
\hline
\end{tabular}




\begin{tabular}{||l|l|l|l||}
\hline \multicolumn{1}{|c|}{1} & \multicolumn{1}{|c|}{2} & \multicolumn{1}{c||}{3} & \multicolumn{1}{c||}{4} \\
\hline $\begin{array}{l}\text { Methods of Conflict } \\
\text { Resolution }\end{array}$ & $\begin{array}{l}\text { Administrative Fiat } \\
\text { - Supervision }\end{array}$ & $\begin{array}{l}\text { Haggling - resort to } \\
\text { courts for enforce- } \\
\text { ment }\end{array}$ & $\begin{array}{l}\text { Haggling based } \\
\text { on the norm of } \\
\text { reciprocity and } \\
\text { arbitration }\end{array}$ \\
\hline $\begin{array}{l}\text { Actor Preferences or } \\
\text { Choices }\end{array}$ & Dependent & Independent & Interdependent \\
\hline $\begin{array}{l}\text { Capacity for Adap- } \\
\text { tation }\end{array}$ & Low & High & Medium \\
\hline
\end{tabular}

Source: Hausner, 2008, p. 401; Powell, 1990, p. 300.

Co-governance performed on various local and regional levels, and on different levels of government requires a more complex type of governance, namely the network form of multi-level governance.

While the methods applied to coordinate activities through organizations (hierarchy) and market are well rooted in the structure of the German public administration, the networks are constantly evolving. Network forms emerge when flexible solutions are needed to respond to changes to the system. Network forms are therefore characterized by interested parties maintaining partnership relationships, resulting in actors voluntarily giving up part of their autonomy in order to pursue the benefits sought (Kopyciński, 2014, p 31). Applying appropriate tools of communication, they use conflicts to build new network systems. To create network systems which are based on a conflict requires organizational structures to be formed in which negotiations can be held, and adequate principles of conduct to be adapted to the needs of these structures. Accepting compromise, network forms remain interdependent. They build network systems balancing out their profits and losses. While their capacity to adapt is lower than that of the market, they hold an advantage over organizations.

When discussing the actors of multi-level governance in Germany its scope should not be neglected. The scope of multi-level governance results from this concept being treated as a form of cooperation of entities within the framework of mutual dependence and includes, for instance, such tasks as bioenergetics, environmental protection, dissemination of culture, tourism and recreation, and promotion of physical culture (Giessen, 2010, p. 5).

However, the scope involves not only tasks, but also the methods of their implementation. In the German literature on the topic, the implementation of tasks within the framework of multi-level governance is based on the principle of partnership (Partnerschaftsprinzip). This principle 
stipulates that the most comprehensive forms of public interest coordination will be provided by urban agglomerations in the form of metropolitan regions constituting an organizational structure in a given area, and the forms of cooperation characteristic of them, i.e. public law and commercial law companies, and public-private partnership models of the following types:

- BOO - Build-Own-Operate,

- BOT - Build-Operate-Transfer,

- BTO - Build-Transfer-Operate,

- DBFO - Design-Build-Finance-Operate.

The following merits of public-private partnerships models are indicated in the German literature on the topic: breaking the monopoly of local governments on the supply of municipal goods and services; depoliticization of management in providing public services to a given community; economic development without imposing debt on the budget of local government units, and thus the state budget, and the introduction of new technologies by private entities. The following shared advantages can be indicated: reduced expenses of a public entity, increasing the standard of services provided, or improving the infrastructure (Richter, 2006). On the other hand, the disadvantages include the risk of increased costs, technological changes, competition, limiting the influence of local governments on the choice of investment, limiting the availability of services and increasing fees for the use of infrastructure facilities (Książek, 2011). The BOT - Buil$\mathrm{d}-$ Operate-Transfer model is the most popular one in Germany.

\section{The role of municipal government in multi-level governance in Germany}

Regardless of the level to which the concept of multi-level governance pertains, it entails the co-management by public administration bodies and other organizational structures operating in their environment for the purpose of regulating socio-economic processes. This concept also encompasses the coordination of public policies which decide about the methods of operating of entrepreneurs, associations, foundations and natural persons (Kopyciński, 2014). A question arises then of how the multi-level governance strategy is implemented at the municipal level.

If the municipal level is treated as one of the levels on which entities participate in co-management, it becomes the platform for network coor- 
dination. In countries where public administration is based on decentralization, state bodies are leaders in establishing the platform for cooperation. Municipalities are the main element of the network system, while the remaining business and social entities form the institutional environment, acting as institutional systems which represent specific needs and interests and take part in co-deciding and cooperation.

Chambers of commerce and industry are significant institutions in the framework of multi-level governance. Germany is the only state where they are partners for local governments and present all the problems faced by business as state bodies. Municipal governments and chambers of commerce and industry in Germany form public corporations, thereby being able to assume the role of an intermediary in the process of emergence of vertical and horizontal network connections, and in strengthening nongovernmental entities (Ansell, 2000). The bottom-up approach should be emphasized here, which is embodied in the variety of partnership forms where trust between the actors is of essential importance.

Municipal governments play a specific role. As socio-economic organizations operating in respective territories, they encompass institutions, the market and their mutual relationships. The group of institutions includes entrepreneurs, associations, foundations and inhabitants. The market is therefore both the object of their operations and their limit. They mutually influence one another by way of feedback. Activity is both an outcome and trigger for another interaction, producing a network of interdependencies. Entities operating in the same territory share similar interests and the need to solve the same problems. The question arises then of how municipalities should coordinate space. Different entities operate on different levels, which is why merely managing them is not sufficient. The levels of interaction need to be taken into consideration, thereby ensuring governance which encompasses all the levels of their interaction, and so multi-level governance.

What follows is that the concept of multi-level governance can be applied whenever the limits and methods of the intervention of public authorities should be established in terms of mitigating market failures and pursuing local development. It can additionally be employed when a public task goes beyond the borders of a municipality becoming a strategy for the coordination of public and private entities.

Multi-level governance is expected to address the development problems of a given territory taking into account the arguments of all actors, and combining the socio-economic and spatial aspects. This approach 
makes it possible to determine the acceptable level and method of providing public services in a participatory manner.

Governance can thus be said to respond to the question of how to implement co-governance while leaving something for the market, or private entities, as well as regulatory and non-regulatory administration bodies. Multi-level governance offers a third way, between solutions characteristic of public entities performing their tasks under the administrative authority granted to them by law, and private organizations operating in the market.

\section{Conclusions}

The above examination leads to the following conclusions:

1. Decentralization of public administration makes it possible to extend multi-level governance to encompass other governmental bodies in the field of business (i.e. chambers of commerce and industry, chambers of agriculture and chambers of crafts).

2. Germany is focused on methods of performing public tasks which assume the participation of private entities in their implementation. The most popular model of public-private partnership is the Build-Operate-Transfer one.

3. Multi-level governance in Germany emerges as a top-down process initiated at the level of Lands and taken down to the level of municipalities. Then, the creation of a network system results from the conviction of central authorities that public tasks are implemented more efficiently thanks to cooperation with private entities whose activities are monitored by regulatory bodies.

4. At the local level, multi-level governance in Germany is embedded in the structure of decentralized public administration by means of the specific type of public task (Gemeinschaftsaufgaben).

5. The introduction of multi-level governance on the local level is preceded by regional governance exercised at the level of Lands, whereby the concept of governance is adapted to the specific nature of a federal state. As a result, this specific nature of the political system in a federal state enables the participatory forms of exercising public tasks more efficiently.

6. Germany is experiencing a strong need to institutionalize and formalize a multi-level governance structure. This is evidenced by the metropol- 
itan regions basing their operations on the forms of public cooperation effected via public and private associations established as commercial law companies.

\section{Bibliography}

Ansell C. (2000), The networked policy. Regional development in Western Europe, "Governance", vol. 13, issue 2, pp. 279-291.

Benz A., Fürst D. (2003), Region-Regional Governance-Regionalentwicklung, in: Regionen erfolgreich steuern, eds. B. Adamaschek, M. Pröhl, Unversitätsverlag Göttingen, Göttingen, pp. 1-123.

Bevir M. (2011), SAGE Handbook of Governance, SAGE, London.

Böcher M. (2008), Instrumentenwandel in der Umwelt- und Naturschutzpolitik und der Politik zur integrierten ländlichen Entwicklung. Theoretische Grundlagen und Strategien der Praxisumsetzung, Dissertation, Göttingen.

Denters B., Rose L. (2005), Towards local governance?, in: Comparing Local Governance. Trends and Developments, eds. B. Denters, L. Rose, Palgrave Mac Millan, New York, pp. 46-62.

Dolnicki B. (2006), Samorząd terytorialny, Zakamycze, Kraków.

Fürst D. (2001), Regional Governance - ein neues Paradigma der Regionalwissenschaften?, "Raumforschung und Raumordnung", no. 59, pp. 370-380.

Fürst D. (2004), Regional Governance, in: Governance - Regieren in komplexen Regelsystmen, ed. A. Benz, VS Verlag für Sozialwissenschaften, Wiesbaden, pp. 49-69.

Giessen L., Böcher M. (2009), Rural Governance, forestry, and the promotion of local knowledge. The case of the German rural development programme "Active Regions", "Small-scale Forestry", vol. 8, pp. 211-230.

Giessen L. (2010), Regional Governance für ländliche Räume - innovativer Ansatz, politischer Gegenwind und der Weg vorwärtz, "Raumforschung und Raumordnung", vol. 68, pp. 3-14.

Hausner J. (2007), Od idealnej biurokracji do zarzadzania publicznego, in: Wymiary życia społecznego, ed. M. Morody, Wydawnictwo Naukowe Scholar, Warszawa, pp. 493-515.

Hausner J. (2008), Zarzadzanie publiczne, Wydawnictwo Naukowe Scholar, Warszawa.

Hooghe L., Marks G. (2001), Types of multi-level governance, "European Integration Online Paper", vol. 5, pp. 1-24.

Jessop B. (2007), Promowanie dobrego rządzenia i ukrywanie jego słabości. Refleksja nad politycznymi paradygmatami i politycznymi narracjami $w$ sferze rządzenia, "Zarządzanie Publiczne", no. 2, pp. 5-25. 
Kaufmann D., Kraay A., Mastruzzi M. (2009), Governance Matters VII Governance Indicators for 1996-2007, DC World Bank, Washington.

Kopyciński P. (2014), Mechanizm koordynacji $w$ polityce innowacyjnej $w$ świetle koncepcji wspólzarządzania wielopoziomowego (multi-level governance). Przykład województwa małopolskiego i świętokrzyskiego, "Zarzadzanie Publiczne", no. 4, pp. 31-46.

Książek E. (2011), Partnerstwo publiczno-prywatne, in: Prawno-organizacyjne aspekty zarządzania w gminie, eds. A. Kożuch, M. Stych, Wydawnictwo Akademii im. Jana Długosza w Częstochowie, Częstochowa, pp. 1-266.

Kuhlmann S., Bogumil J., Grohs S. (2008), Evaluating Administrative Modernization In German Local Governments. Success of Failure of the "New Steering Model?", "Public Administration Review", vol. 5, pp. 851-863.

Kuhlmann S., Bogumil J., Grohs S., Ohm A. (2007), Zehn Jahre Neues Steuerungsmodell: eine Bilanz kommunaler Verwaltungsmodernisierung, Edition Sigma, Berlin.

Lepsius O. (2002), Geld als Schutsgut der Eigentumsgarantie, "Juristen Zeitung”, vol. 757, pp. 313-321.

Mutius A. von, Henneke H.-G. (1985), Kommunale Finanzausstattung und Verfassungsrecht. Dargestellt am Beispiel der nordrhein-westfälischen Gemeindefinanzierungsgesetze 1983 und 1984, Recinger, Siegburg.

Powell W. W. (1990), Neither market or hierarchy. Network forms of organization, "Research in Organizational Behaviour", vol. 12, pp. 295-336.

Richter D. (2006), Kommunales Vermögen und seine Verwaltung, in: Recht der Kommunalfinanzen. Abgaben, Haushalt, Finanzausgleich, ed. H.-G. Henneke, C.H. Beck, München.

Scharpf F. (2014), Zapiski o teorii zarzadzania wielopoziomowego $w$ Europie, "Zarządzanie Publiczne", no. 4, pp. 76-99.

Strumińska-Kutra M. (2012), Rola badań społecznych $w$ refleksyjnych procesach metarządzenia. Zarys perspektywy teoretycznej i metodologicznej, "Zarządzanie Publiczne", no. 4, pp. 17-29.

Sześciło D. (2012), Niemiecki Steuerungsmodell. Nowe zarządzanie publiczne w samorządzie lokalnym, "Samorząd Terytorialny", no. 1-2, pp. 42-52.

\section{Zastosowanie multi-level governance w samorządzie terytorialnym w Republice Federalnej Niemiec}

\section{Streszczenie}

Samorząd gminny w Niemczech, wykonując zadania publiczne w ramach multilevel governance, pełni najważniejszą rolę w układzie sieciowym. Jako organ państwa inicjuje i zmienia formy koordynacji działań zbiorowych. Głównym problemem, 
jaki legł u podstaw artykułu jest używanie siatki pojęciowej, występującej w zdekoncentrowanej strukturze administracji publicznej w krajach anglosaskich, do opisu multi-level governance w zdecentralizowanych formach administracji publicznej. Celem głównym artykułu jest zaprezentowanie w jaki sposób koncepcja multi-level governance została dostosowana do specyfiki niemieckiego samorządu gminnego oraz na czym polega jej istota. Celowi głównemu podporządkowano następujące pytania badawcze: Jaka jest różnica w genezie governance w Niemczech w porównaniu do tradycji państw anglosaskich? W jaki sposób są realizowane zadania publiczne w ramach multi-level governance w Niemczech? Jakie są formy organizacyjno-prawne wykonywania zadań publicznych? Artykuł został przygotowany według założeń nowego instytucjonalizmu. W celu zaprezentowania sposobów wykonywania zadań publicznych w koncepcji multi-level governance zastosowano metodę funkcjonalną, która umożliwiła wyłonienie tych zadań, które mogą być realizowano zarówno przez jednostki samorządu terytorialnego, jak i instytucje samorządu gospodarczego. Uzupełniając rozważania zastosowano również metodę instytucjonalną pokazującą specyfikę współpracy samorządu gminnego z innymi podmiotami publicznoprawnymi i prywatnoprawnymi. Z badań nad multi-level governance w Niemczech autorka wyciągnęła trzy wnioski, wokół których powstał artykuł. Po pierwsze, powstanie multi-level governance w Niemczech oparte jest na działaniach odgórnych i następuje od kraju związkowego do gmin (top-down). Tworzenie układu sieciowego wynika wówczas z przekonania władz państwowych o efektywniejszej realizacji zadań publicznych opartej na współpracy z podmiotami prywatnymi, których działania moderowane są przez podmioty władcze. Po drugie, wprowadzenie multi-level governance na poziomie lokalnym poprzedzone jest regional governance na szczeblu krajów związkowych stanowiącą dostosowanie koncepcji governance do specyfiki państwa federalnego. Po trzecie, multi-level governance zostało wprowadzone w strukturę samorządu gminnego za pośrednictwem specjalnego typu zadań publicznych (Gemeinschaftsaufgaben).

Słowa kluczowe: samorząd gminny, samorząd terytorialny, zadania publiczne samorządu gminnego, multi-level governance, zarządzania publiczne, governance 